\title{
An Analysis on the Effect of Entrepreneurial Motivation on Business Performance of Plasma Broiler Breeders at the Riau Province
}

\author{
Cepriadi $^{1,3, *}$, Darsono $^{2}$, Sutrisno Hadi ${ }^{2}$, Rosnita $^{3}$ \\ ${ }^{I}$ Department of Agriculture Science gradueted School, Sebelas Maret University, Surakarta, Indonesia \\ ${ }^{2}$ Department of Agribusiness, Faculty Of Agriculture, Sebelas Maret University, Surakarta, Indonesia \\ ${ }^{3}$ Department of Agribusiness, Faculty Of Agriculture, Riau University, Pekanbaru, Indonesia \\ *Corresponding author.Email: cepriadi_cecep@ymail.com
}

\begin{abstract}
This study aims to analyze the effect of motivation on business performance broiler breeders in Riau province. Sampling is done using convenience sampling by adjusting the factors required by the researcher. The data used are primary data and secondary data. Data analysis was done by using Structural Equation Modeling (SEM). From the research results obtained the value of path coefficient of 0.239 with current ratio 2.780 and $\mathrm{P}$ value 0.004 . The current ratio value is greater than the statistical table $(1,960)$ and the $\mathrm{P}$ value is less than 0.05 which means the motivation has significant effect on the performance. The value of the coefficient of the path marked positive has the meaning that the higher the motivation the better the performance.
\end{abstract}

Keywords: motivation, performance, broiler breeders

\section{INTRODUCTION}

The livestock sub-sector, poultry development is the important thing to do, because poultry has a fairly high demand in the market along with an increase in population, public awareness of nutritional value, living standards and urbanization and public consumption to meet animal protein needs. One type of poultry that is widely cultivated today is broiler as the biggest contributor to the national meat supply $[1,10]$.

Contract farming partnership pattern is very helpful for broiler breeders in an effort to reduce the value of losses due to various business risks, but this cannot fully help broiler breeders in running their business. The success of broiler breeders in contract farming partnerships is determined by the participation of farmers in cultivate the livestock. Farmer participation in livestock business is aimed at improving the welfare of broiler breeders $[2,8]$.

Farmers' participation in their livestock business is reflected in the performance of the livestock business carried out. Business performance can be assessed by increasing business scale, income, competitive advantage, work planning, communication and cooperation. In the reality, it is easy to find broiler breeders who move partner companies. One of the driving factors for broiler breeders switching partners is the suitability of the contract with the socio-economic benefits are obtained by broiler breeders and the motivation given by the company to the breeders themselves. The ideal partner relationship for breeders and companies should be mutually beneficial relationships $[3,5]$.

\section{METHODS}

Research Methods and Respondent Retrieval Techniques

The method used in this study was a survey method, where for information collection used questionnaire tools. Respondent withdrawal technique is done by non probability sampling method. In this study the nonprobability sampling technique used was convenience sampling. Convenience sampling is the technique of taking respondents based on the consideration of the researcher who considers the desired elements are represented in the sample taken. Respondents in this study were broiler breeders who partnered with contract farming partnership in the research location with the number of respondents selected as many as 163 people.

\section{Variables and Measurement}

The variables that will be measured in this study are variables of the behavior and business performance of the broiler breeder's. The indicators of motivation variables are company policy $(\mathrm{X} 1)$, supervision $(\mathrm{X} 2)$, interpersonal relationships (X3), rewards (X4), working conditions (X5), achievement (X6), awards (X7), jobs (X8), and responsibility (X9). While indicators of business performance variables are increasing business scale (Y1), increasing income (Y2), competitive advantage (Y3), work planning (Y3), planning (Y4), communication (Y5) and cooperation (Y6) . 


\section{Data analysis}

Data analysis techniques used in this study are Structural Equation Model (SEM). The research model being developed will be described in the path diagram to make it easier to see the causality relationships being tested. The program language in SEM will convert the path picture diagram into an equation then the equation becomes an estimate [4].

In drawing path diagrams, the relationships between constructs are shown through arrows. A straight arrow shows a direct causality relationship between one construct and another construct. The curved lines between constructs and arrows at each end show the correlation between constructs. The constructs that are built in the path diagram are divided into two construct groups namely exogenous constructs and endogenous constructs [4].

Respondents' preference answers to the variables of entrepreneurial behavior and business performance were assessed using a Likert scale, can be seen in Table 1 below.

Table 1. Score of respondent's answer number

\begin{tabular}{|l|l|l|l|}
\hline No. & Respondent answer & Score & Scale \\
\hline $\mathbf{1}$ & Very bad & 1 & $1.00-1.79$ \\
\hline $\mathbf{2}$ & Not good & 2 & $1.80-2.59$ \\
\hline $\mathbf{3}$ & Pretty good & 3 & $2,60-3,39$ \\
\hline $\mathbf{4}$ & Good & 4 & $3,40-4,19$ \\
\hline $\mathbf{5}$ & Very good & 5 & $4,20-5,00$ \\
\hline
\end{tabular}

Structural equation analysis requires interval data, so all ordinal-scale variables are first transformed into interval forms through the Method of Succesive Interval (MSI).

\section{Data analysis using the SEM method}

\section{a. Model Development}

The development of this model is done by arranging any variables that affect brand equity.

\section{b. Development of Flow Charts}

The theory-based model that has been carried out is then used to make path diagrams. Path diagrams are intended to make it easier for researchers to see the relationships that they want to test.

\section{c. Flow chart conversion into SEM Equations}

Exogenous and endogenous construct equations can be seen in the structural model.

d. Selection of Input Matrix and Estimation Technique This study will examine the causality relationship, so that the matrix used as the SEM input is the covariance matrix. Covariance matrices are used for explanations or predictions of phenomena studied. The estimation technique used is maximum likelihood in accordance with the conditions of the sample being tested is 100 to 200 .

\section{e. Assessing Identification Problems}

Problem identification will be seen in a situation where the standard error for one or several coefficients is very large or a very high correlation between coefficients $(>0.9)$.

\section{f. Model Evaluation}

In this step the accuracy of the model is evaluated, through various stages of goodness fit criteria. Test the suitability of the model as follows in Table 2.

Table 2. Criteria for Goodness Fit (Suitability Model)

\begin{tabular}{|c|c|c|}
\hline $\begin{array}{l}\text { Goodness } \\
\text { of Fit } \\
\text { index }\end{array}$ & Cut off Value & Description \\
\hline $\begin{array}{l}\text { X2-chi- } \\
\text { square }\end{array}$ & $\begin{array}{l}<\mathrm{df} \text { with } \alpha= \\
0.05\end{array}$ & $x^{2} / d f>5$ \\
\hline RMSEA & $\leq 0.08$ & $\begin{array}{l}\text { RMSEA } 80.08 \text { (good fit) } \\
\text { RMSEA }<0.05 \text { (close fit) }\end{array}$ \\
\hline GFI & $\geq 0.90$ & $\begin{array}{l}0.80 \leq \text { GFI } \\
\text { (marginal fit) }\end{array}$ \\
\hline AGFI & $\geq 0.90$ & $\begin{array}{l}0.80 \leq \text { AGFI } \leq 0.9 \\
\text { (marginal fit) }\end{array}$ \\
\hline $\begin{array}{l}\text { CMIN / } \\
\text { DF }\end{array}$ & $\leq 2.00$ & ( \\
\hline TLI & $\geq 0.95$ & - \\
\hline CFI & $\geq 0.95$ & $\begin{array}{l}\text { CFI }>0.9(\text { marginal fit }) \\
\text { CFI } \geq 0.95(\text { good fit })\end{array}$ \\
\hline
\end{tabular}

\section{RESULTS AND DISCUSSION}

\section{Validity Test Results Discriminant Validity Fornell-Larcker}

\begin{tabular}{|l|l|l|}
\hline & Performance & Motivation \\
\hline Performance & 0.767 & \\
\hline Motivation & 0.687 & 0.745 \\
\hline
\end{tabular}

Another method for assessing discriminant validity is the measurement by themethod Fornell-Larcker can be done by comparing the square roots of AVE with latent vertical correlation. Discriminant validity is said to be good if the square root on AVE along the diagonal line is greater in correlation between one construct and the other. From the table above it can be seen that the square root value of AVE along the diagonal line is greater the correlation between one construct and the other, so it can be concluded that the construct has a good level of validity.

Test Results Cronbach's Alpha \& Composite Reliability

\begin{tabular}{|l|l|l|}
\hline & Cronbach's Alpha & Composite Reliability \\
\hline Performance & 0.860 & 0.895 \\
\hline Motivation & 0.799 & 0.861 \\
\hline
\end{tabular}


According to [6], the magnitude of the reliability coefficient that must be met by a measuring instrument is 0.7 . If the reliability coefficient of all items is greater or equal to 0.7 then the instrument items are declared reliable. Based on the table above, it is known that all instruments are considered reliable because the cronbach's alpha value \& composite reliability is greater than 0.7 .

\section{Structural Model}

Based on the hypothesis model developed that indirectly motivation is assumed to be causal with business performance through the dimensions of business performance, an initial path diagram that has no estimation value. Next is to create a structural model that has an estimated value based on the initial path diagram.

After the structural model is made, then the next is to do the test. Testing of the goodness of fit model must be carried out to ensure that the structural model that has been prepared can explain the direction of the relationship and the direction of influence appropriately and does not lead to a prediction bias [7].

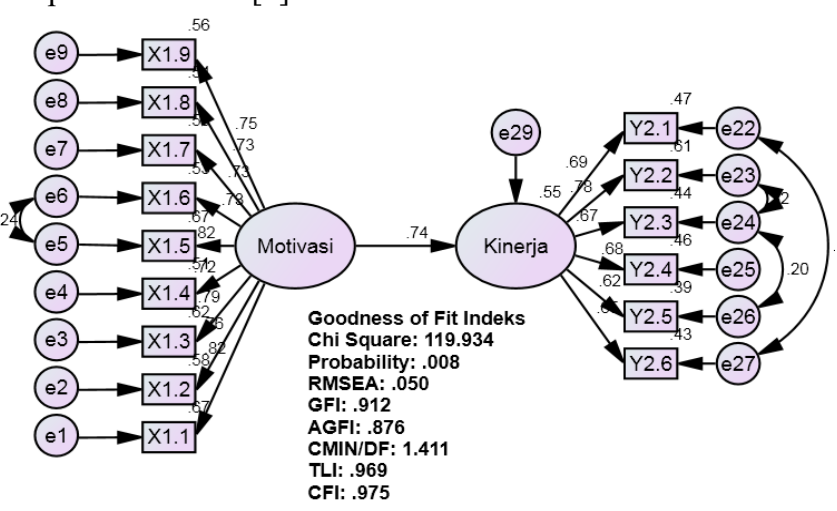

Figure 1. Structural Model Preliminary

Based on Table 3. It can be seen that the criteria in the goodness of fit test for the initial structural model generally do not meet the recommended criteria. Therefore, a modification process is needed to improve the model. In the modification model, an additional relationship is made to the variable in order to reduce the chi-square value.

After a model modification experiment based on the modification index issued by the AMOS program, the model produced a better evaluation than before. The results of running a full model that has been modified can be seen in Figure 1.

Table 3. Testing Goodness of Fit Model

\begin{tabular}{|l|l|l|l|}
\hline $\begin{array}{c}\text { Goodness of } \\
\text { fit index }\end{array}$ & $\begin{array}{c}\text { Cut-off } \\
\text { value }\end{array}$ & $\begin{array}{c}\text { Model } \\
\text { results }\end{array}$ & Description \\
\hline Chi Square & - & 119934 & Not fit \\
RMSEA & $\leq 0: 08$ & 0050 & Close fit \\
GFI & $0.90 \geq$ & 0.912 & Marginal fit \\
AGFI & $\geq 0.90$ & 0.876 & Marginal fit \\
CMIN / DF & $2: 00 \leq$ & 1.411 & Good fit \\
TLI & $\geq 0.95$ & 0.959 & Marginal fit \\
CFI & $0.90 \geq$ & 0.975 & Good fit \\
\hline
\end{tabular}

Table 4. Goodness of Fit Testsmodel

\begin{tabular}{|l|l|l|l|}
\hline $\begin{array}{c}\text { Goodness of } \\
\text { fit index }\end{array}$ & $\begin{array}{c}\text { Cut-off } \\
\text { value }\end{array}$ & Result & Description \\
\hline Chi Square & -8 & 102.480 & Not fit \\
RMSEA & 0.08 & 0.039 & Close fit \\
GFI & $\geq 0.90$ & 0.925 & Good fit \\
AGFI & $\geq 0.90$ & 0.890 & Marginal fit \\
CMIN / DF & $\leq 2.00$ & 1.250 & Good fit \\
TLI & $\geq 0.95$ & 0.981 & Good fit \\
CFI & $\geq 0.90$ & 0.985 & Good fit \\
\hline
\end{tabular}

Based on Table 4. It can be seen that the evaluation model for the full model structural modification has shown better criteria where for each size the value of goodness of fit is appropriate except for thesize Chi-Square whose value still does not meet the specified criteria. But overall it can be concluded that the structural model that has been modified has produced the expected level of estimation. According [5], if two or more of the entire GOF used have shown a good model fit (goodfit), then the model can already be said to be good. To test the proposed research hypothesis it would be better to use the results of the modified structural model [9].

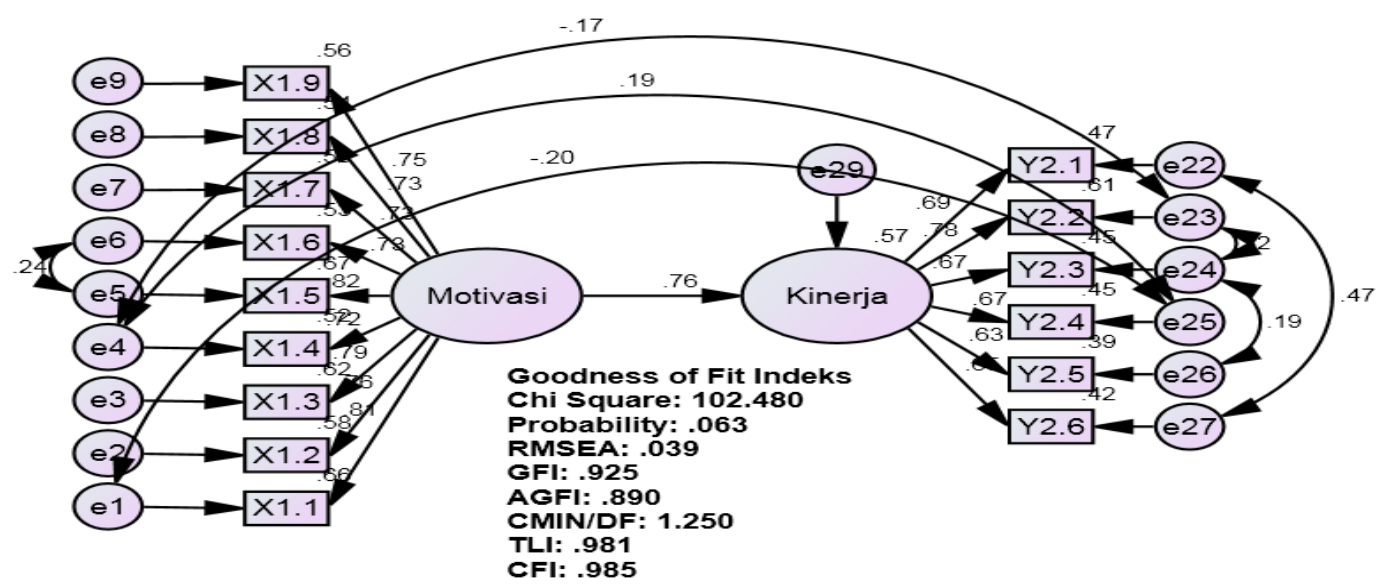

Figure 2. Structural Modification Model 
Table 5. Standardized Regression Model Structural Modification Weight

\begin{tabular}{|l|l|l|l|l|l|l|l|}
\hline \multirow{2}{*}{ Performance } & & & Estimate & S.E. & C.R. & P & Label \\
\cline { 2 - 8 } & $<---$ & Motivation & .647 & .088 & 7.336 & 0.00 & par_10 \\
\hline X1.3 & $<---$ & Motivation & .961 & .084 & 11.476 & 0.00 & par_1 \\
\hline X1.4 & $<---$ & Motivation & .858 & .084 & 10.255 & 0.00 & par_2 \\
\hline X1.5 & $<---$ & Motivation & 1.026 & .086 & 11.995 & 0.00 & par_3 \\
\hline X1.6 & $<---$ & Motivation & .916 & .090 & 10.214 & 0.00 & par_4 \\
\hline X1.7 & $<---$ & Motivation & .961 & .094 & 10.256 & 0.00 & par_5 \\
\hline Y2.2 & $<---$ & Performance & .819 & .099 & 8.262 & 0.00 & par_6 \\
\hline Y2.3 & $<---$ & Performance & .765 & .107 & 7.157 & 0.00 & par_7 \\
\hline Y2.4 & $<---$ & Performance & .857 & .116 & 7.414 & 0.00 & par_8 \\
\hline Y2.5 & $<---$ & Performance & .875 & .126 & 6.943 & 0.00 & par_9 \\
\hline X1.9 & $<---$ & Motivation & .845 & .080 & 10.606 & 0.00 & par_11 \\
\hline X1.8 & $<---$ & Motivation & .808 & .078 & 10.392 & 0.00 & par_12 \\
\hline X1.1 & $<---$ & Motivation & 1.000 & & & & \\
\hline X1.2 & $<---$ & Motivation & 1.003 & .092 & 10.962 & 0.00 & par_13 \\
\hline Y2.1 & $<---$ & Performance & 1.000 & & & & \\
\hline Y2.6 & $<---$ & Performance & .813 & .082 & 9.950 & 0.00 & par_18 \\
\hline
\end{tabular}

Based on the results of the hypothesis test presented in Table 5 it can be seen that the significance value for all influence relationships is significant because the p-value value is generated below $0.05(\alpha=5 \%)$. According to Sugiyono (2010), the hypothesis is significant if the value of $p<0.005$ thus can be said that there is no difference between theoretical models and empirical data, meaning that the theoretical model is in accordance with empirical data.

\section{CONCLUSION}

The conclusion of this study is all motivation variables : company policy (X1), supervision (X2), interpersonal relationship (X3), reward (X4), working conditions (X5), achievement (X6), award (X7), work (X8), and responsibility (X9) has a significant influence on performance variables: increasing business scale (Y1), increasing income (Y2), competitive advantage (Y3), work planning (Y3), planning (Y4), good communication (Y5) and good cooperation (Y6) with different significance values from one another.

\section{REFERENCES}

[1] Afrrev Ijah. 2013. The Influence of Motivation on Employees' Performance: A Study of Some Selected Firms in Anambra State. An International Journal of Arts and Humanities Bahir Dar, Ethiopia Vol. 2 (3), S/No 7, July, 2013: 134-151.

[2] Belly, onanda. 2015. The Effect of Motivation on Job Performance. International Journal of Scientific and Research Publications, Volume 5, Issue 9, 2015.

[3] Campos, Héctor Montiel and Francisco Alfonso Aguilar Valenzuela. 2013. The Relationship Between Entrepreneurial Orientation, Time Orientation And Small Business Performance: An Evidence From
Mexico. Revista da Micro e Pequena Empresa, Campo Limpo Paulista, v.7, n.1, p.48-63, 2013.

[4] Ferdinand. 2002. Management Research Methods. BP Undip. Semarang

[5] Ghozali I and Fuad. 2005. Structural Equation Modeling (Theory, Concept, and Application). Diponegoro University Publishing Agency. Semarang. Page 3.

[6] Girindra K and Kamal M. 2012. Analysis of the Influence of Price, Promotion, Distribution, Product Quality Perceptions, and Market Segmentation on the Success of Yamaha Motorcycle Products (Study on Yamaha Motor Dealer Semarang). Journal of Economic and Business Management 2 (4). Page 110

[7] Khan, Taslim. 2014. Job Satisfaction and Job Perfomance, A Study on Colleges of Saudi Arabia. Journal of Scientific Research and Reports. Vol 3(23). Hal 2972-2981.

[8] Pham, Hien Hoang. 2016. The Impacts of Job Motivation and Job Satisfaction on Job Perfomance Among Employees of Retail Banking Sector in Vietnam. International J. of Business. Vol 5. Pp 1-27.

[9] Roos, Wanda and Eeden, René Van. 2010. The relationship between employee motivation, job satisfaction and corporate culture. SA Journal of Industrial Psychology. Vol. 34 No. 1 pp. $54-63$.

[10] Saleem, Rizwan. et al. 2010. Effect of Work Motivation on Job Satisfaction in Mobile Telecommunication Service Organizations of Pakistan. International Journal of Business and Management Vol. 5, No. 11; November 2010.

[11] Singh, S. K. and Tiwari, Vivek. 2011. Relationship Between Motivation and Job Satisfaction of The White Collar Employees :A Case Study. Management Insight. Vol. VII, No. 2; 2011. 